\title{
41. COCCOLITH STRATIGRAPHY, ARABIAN AND RED SEAS, DEEP SEA DRILLING PROJECT LEG $23^{1}$
}

\author{
David Bukry, United States Geological Survey, La Jolla, California
}

\section{INTRODUCTION}

Leg 23 of the Deep Sea Drilling Project, March to May 1972, which began at Colombo, Ceylon and ended at Djibouti, French Territory of the Afars and the Issas, investigated the Arabian and Red Seas, recovering 311 cores at 12 drilling sites (Figure 1; Table 1). Light-microscope

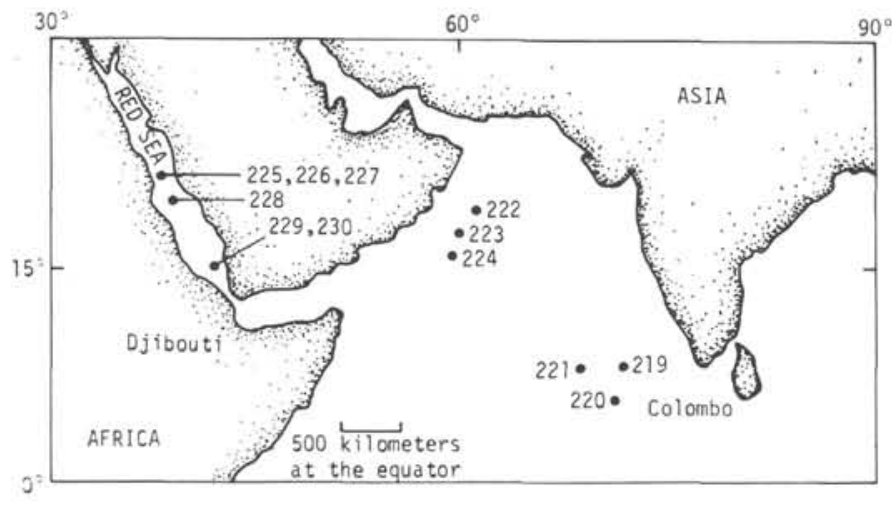

Figure 1. Location of sites cored during DSDP Leg 23.

TABLE 1

Location, Water Depth, Penetration, and Number of Cores Cut at DSDP Sites in the Arabian and Red Seas

\begin{tabular}{|c|c|c|c|c|c|}
\hline Site & $\begin{array}{l}\text { Latitude } \\
\text { (N) }\end{array}$ & $\begin{array}{l}\text { Longitude } \\
\text { (E) }\end{array}$ & $\begin{array}{c}\text { Water } \\
\text { Depth } \\
\text { (m) }\end{array}$ & $\begin{array}{l}\text { Penetration } \\
\text { (m) }\end{array}$ & Cores \\
\hline
\end{tabular}

Arabian Sea

$\begin{array}{llllrl}219 & 09^{\circ} 01.75^{\prime} & 72^{\circ} 52.67^{\prime} & 1764 & 411 & 42 \\ 220 & 06^{\circ} 30.97^{\prime} & 70^{\circ} 59.02^{\prime} & 4036 & 350 & 21 \\ 221 & 07^{\circ} 58.18^{\prime} & 68^{\circ} 24.37^{\prime} & 4650 & 270 & 19 \\ 222 & 20^{\circ} 05.49^{\prime} & 61^{\circ} 30.56^{\prime} & 3546 & 1300 & 36 \\ 223 & 18^{\circ} 44.98^{\prime} & 60^{\circ} 07.78^{\prime} & 3633 & 740 & 41 \\ 224 & 16^{\circ} 32.51^{\prime} & 59^{\circ} 42.10^{\prime} & 2500 & 792 & 11\end{array}$

Red Sea

\begin{tabular}{rllrrr}
225 & $21^{\circ} 18.58^{\prime}$ & $38^{\circ} 15.11^{\prime}$ & 1228 & 240 & 29 \\
226 & $21^{\circ} 20.51^{\prime}$ & $38^{\circ} 04.93^{\prime}$ & 2169 & 14 & 2 \\
227 & $21^{\circ} 19.86^{\prime}$ & $38^{\circ} 07.97^{\prime}$ & 1795 & 359 & 45 \\
228 & $19^{\circ} 05.16^{\prime}$ & $39^{\circ} 00.20^{\prime}$ & 1038 & 325 & 40 \\
229 & $14^{\circ} 46.09^{\prime}$ & $42^{\circ} 11.47^{\prime}$ & 852 & 212 & 23 \\
230 & $15^{\circ} 19.00^{\prime}$ & $41^{\circ} 50.05^{\prime}$ & 832 & 19 & 2 \\
\hline
\end{tabular}

\footnotetext{
${ }^{1}$ Publication authorized by the Director, U. S. Geological Survey.
}

techniques were used to study the coccoliths of 289 samples from these cores. The zonation employed in zonal assignments of core samples (summarized in Figures 2 and 3 ) is based on Bukry (1971, in press).

\section{INDO-PACIFIC CORRELATION WITH DISCOASTER FORMOSUS}

The calcareous nannofossil Discoaster formosus was first described from Deep Sea Drilling Project (DSDP) Sites 62 and 63 in the western equatorial Pacific north of New Guinea (Martini and Worsley, 1971); the species has since gone unrecorded. Its type level, the middle Miocene Sphenolithus heteromorphus Zone, has been cored repeatedly in all the major oceans. Abundant $D$. formosus populations have now been found $87^{\circ}$ to the east in the same zone at DSDP Site 223 in the Arabian Sea, south of Oman. The species composition of the new and type assemblages is practically identical, and an analysis of the ray number in the star-shaped $D$. formosus specimens shows a remarkably similar distribution. Three to eight rays are developed in this species. Populations from DSDP $63.1-12-2,80-81 \mathrm{~cm}(167 \mathrm{~m})$ and DSDP 223-23-2, 50-51 $\mathrm{cm}(452 \mathrm{~m})$ have the following percents, respectively, based on counts of 300 specimens: three-rayed, $2 \%$ and $3 \%$; five-rayed, $12 \%$ and $14 \%$; six-rayed, $79 \%$ and $77 \%$; sevenrayed, $7 \%$ and $5 \%$; eight-rayed, $0 \%$ and $<1 \%$. Identical age and paleoecology within the $S$. heteromorphus Zone are indicated at these two widely separated areas. The lack of occurrences of $D$. formosus at other Indo-Pacific sites indicates that the species is extremely restricted in stratigraphic range or ecologic tolerance and could prove to be a diagnostic fossil when found at other localities.

\section{REFERENCES}

Bukry, D., 1971. Cenozoic calcareous nannofossils from the Pacific Ocean: San Diego Soc. Nat. Hist. Trans., v. 16, p. 303.

in press. Low-latitude coccolith biostratigraphic zonation. In Edgar, N. T., Sanders, J. B., et al., Initial Reports of the Deep Sea Drilling Project, Volume XV: Washington (U. S. Government Printing Office).

Martini, E. and Worsley, T., 1971. Tertiary calcareous nannoplankton from the western equatorial Pacific: In Winterer, E. L., Riedel, W. R., et al., Initial Reports of the Deep Sea Drilling Project, Volume VII: Washington (U. S. Government Printing Office), p. 1500. 


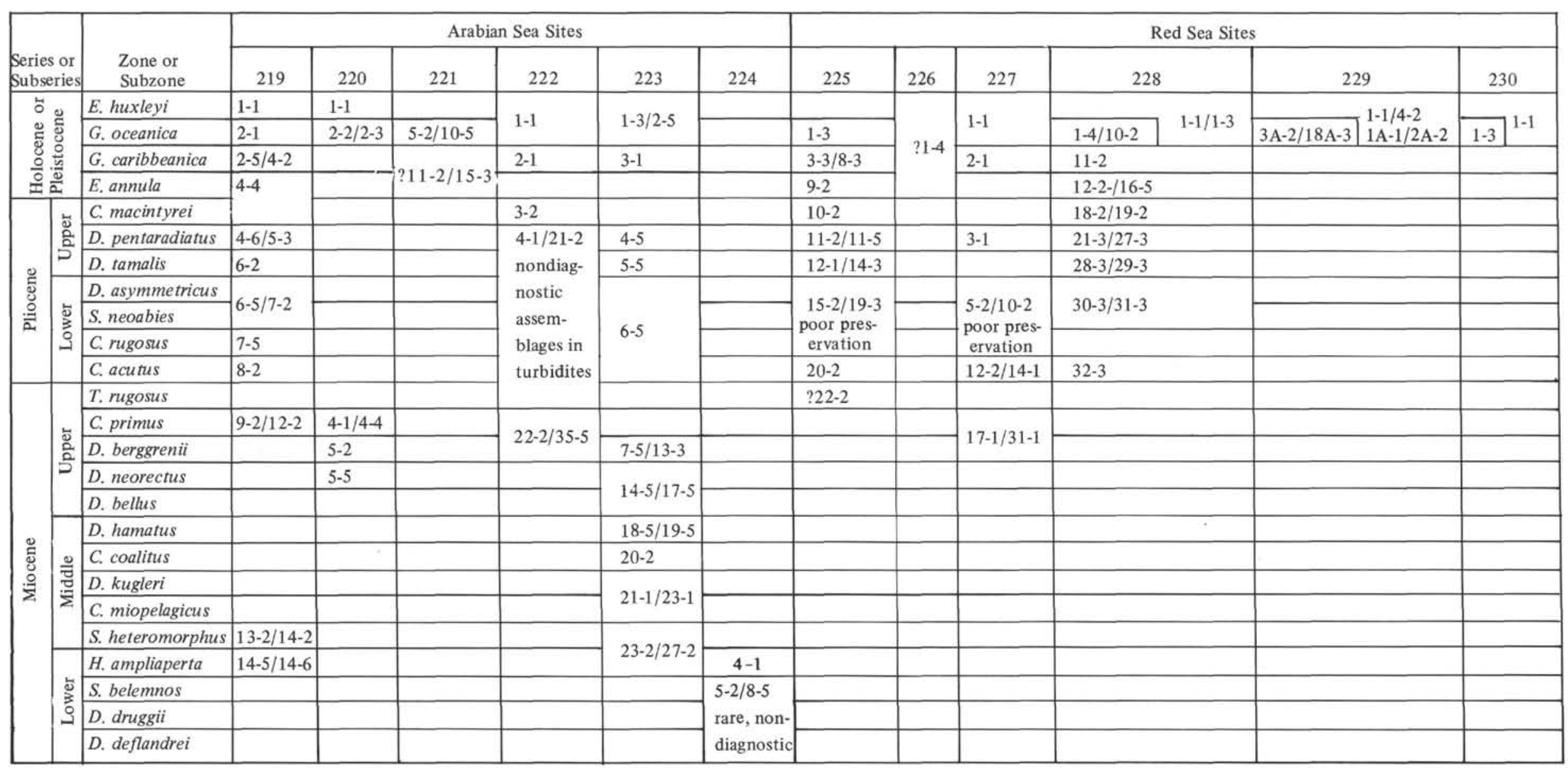

Figure 2. Coccolith zonation of Neogene sediment from the Arabian and Red Seas, DSDP Leg 23. The numbers assigned to zonal intervals are core and section numbers of samples examined. A core is typically 9 meters long, and a section is a sixth part of a core, 1.5 meters, both numbered from the top. Where a zone or subzone is represented in samples from two or more core sections, the highest and lowest sections are listed. 


\begin{tabular}{|c|c|c|c|c|c|c|c|}
\hline \multirow{2}{*}{\multicolumn{2}{|c|}{$\begin{array}{l}\text { Series or } \\
\text { Subseries }\end{array}$}} & \multirow{3}{*}{$\begin{array}{c}\begin{array}{c}\text { Zone or } \\
\text { Subzone }\end{array} \\
\text { C. abisectus }\end{array}$} & \multicolumn{5}{|c|}{ Arabian Sea Sites } \\
\hline & & & 219 & 220 & 221 & 223 & 224 \\
\hline \multirow{7}{*}{$\begin{array}{l}\mathscr{\Xi} \\
8 \\
0 \\
0 \\
0\end{array}$} & \multirow{4}{*}{ 岕 } & & & & & & $9-1$ \\
\hline & & S. ciperoensis & & $6-2 / 8-5$ & $16-5 / 17-2$ & $28-5$ & \\
\hline & & S. distentus & & & & $29-5$ & \\
\hline & & S. predistentus & $15-2 / 15-5$ & $9-2 / 10-2$ & & $30-5 / 31-1$ & \\
\hline & \multirow{3}{*}{$\begin{array}{l}\text { 章 } \\
0 \\
0\end{array}$} & $R$. hillae & $? 16-2$ & & & & \\
\hline & & C. formosa & $16-4$ & & & $31-3$ & \\
\hline & & C. subdistichus & & & & & \\
\hline \multirow{12}{*}{ 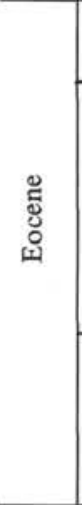 } & \multirow{2}{*}{ : } & R. reticulata & $17-2 / 17-5$ & $11-1$ & & $32-1$ & \\
\hline & & D. $\tan i$ & $18-2$ & & & & \\
\hline & \multirow{6}{*}{$\frac{0}{\tilde{z}}$} & D. saipanensis & $19-2 / 19-5$ & & $18-3$ & $32-3 / 33-2$ & $10-2$ \\
\hline & & D. bifax & & & $? 18-6$ & & \\
\hline & & C. staurion & $20-2 / 21-2$ & $12-2 / 12-5$ & & & \\
\hline & & C. gigas & & $13-2 / 14-1$ & & & \\
\hline & & D. strictus & & $? 14-2 / ? 14-3$ & & & \\
\hline & & R. inflata & & $15-2 / 15-5$ & & & 11-1 \\
\hline & \multirow{4}{*}{ ڤ్ } & D. kuepperi & & $15-6 / 16-2$ & & & \\
\hline & & D. lodoensis & & $17-1$ & & & \\
\hline & & \begin{tabular}{|l|} 
T. orthostylus \\
\end{tabular} & & $18-2 / 18-3$ & & & \\
\hline & & D. diastypus & & & & & \\
\hline \multirow{3}{*}{ 良 } & \multirow{3}{*}{ 岕 } & D. multiradiatus & \multirow{3}{*}{$? 12 \mathrm{~A}-2 / 12 \mathrm{~A}-5$} & & & & \\
\hline & & D. nobilis & & & & & \\
\hline & & D. mohleri & & & & & \\
\hline
\end{tabular}

Figure 3. Coccolith zonation of Paleogene sediment recovered from the Arabian

Sea, DSDP Leg 23. 